\title{
PKM MANAJEMEN STRESS PADA PANDEMI COVID-19 DI DESA KUOK KECAMATAN KUOK
}

\author{
Alini $^{1}$, Langen Nidhana Meisyalla ${ }^{2}$ \\ ${ }^{1,2)}$ Program Studi Sarjana Keperawatan, Fakultas Ilmu Kesehatan, Universitas Pahlawan Tuanku Tambusai \\ e-mail: alini_09@yahoo.com
}

\begin{abstract}
Abstrak
Pandemi COVID-19 merupakan bencana non alam yang dapat memberikan dampak pada kondisi kesehatan jiwa dan psikososial setiap orang. Menurut WHO (2020), munculnya pandemi menimbulkan stress pada berbagai lapisan masyarakat. Survey yang dilakukan oleh Ikatan Perawat Kesehatan Jiwa (IPKJI) dan Departemen Keperawatan Jiwa UI pada 2.155 perawat di RS dan Puskesmas selama pendemi Covid-19 menunjukkan bahwa sebanyak 70,3\% (1557 orang) merasa cemas, tegang dan khawatir akan terkena wabah Covid-19. Berdasarkan survey yang dilakukan di Desa Kuok Kecamatan Kuok didapatkan data bahwa sebagaian orang merasa khawatir, tegang, dan cemas akan tertular Covid-19. Upaya promosi kesehatan jiwa yang dilakukan pemerintah belum maksimal menjangkau masyarakat. Hal ini dibuktikan dengan belum adanya kader kesehatan jiwa di Desa Kuok. Pelayanan kesehatan jiwa masih berfokus pada kuratif seperti rujukan pasien yang mengalami masalah kesehatan jiwa. Apabila upaya promotif dan preventif kesehatan jiwa tidak gencar dilakukan maka angka masalah kejiwaan dan gangguan jiwa dapat meningkat. Salah satu upaya yang dapat dilakukan untuk memelihara, menjaga dan meningkatkan kesehatan jiwa pada masa pandemi Covid-19 adalah dengan cara mengelola stress atau manajemen stress. Manajemen stress adalah dimana individu melakukan pengontrolan atau pengatuuran stress. Tujuannnya agar individu mengenal penyebab stress dan mengetahui tehnik-tehnik mengelola stress, sehingga individu tersebut lebih baik dalam menguasai stress dalam kehidupan, sehingga pada akhirnya kondisi sehat mental dapat dicapai.
\end{abstract}

Kata kunci: Covid-19, Kesehatan Jiwa, Manajemen Stress, Pandemi

\begin{abstract}
The COVID-19 pandemic is a non-natural disaster that can have an impact on everyone's mental and psychosocial health conditions. According to WHO (2020), the emergence of a pandemic has caused stress on various levels of society. A survey conducted by the Association of Mental Health Nurses (IPKJI) and the UI Department of Mental Nursing on 2,155 nurses in hospitals and health centers during the Covid-19 epidemic showed that as many as $70.3 \%$ (1557 people) felt anxious, tense and worried about being hit by the Covid-19 outbreak. 19. Based on a survey conducted in Kuok Village, Kuok District, it was found that some people felt worried, tense, and anxious about contracting Covid-19. The mental health promotion efforts carried out by the government have not maximally reached the community. This is evidenced by the absence of mental health cadres in Kuok Village. Mental health services still focus on curatives such as referral of patients with mental health problems. If promotive and preventive mental health efforts are not carried out intensively, the number of mental problems and mental disorders can increase. One of the efforts that can be made to maintain, maintain and improve mental health during the Covid-19 pandemic is by managing stress or stress management. Stress management is where individuals control or manage stress. The goal is that individuals recognize the causes of stress and know techniques for managing stress, so that the individual is better at mastering stress in life, so that in the end a healthy mental state can be achieved.
\end{abstract}

Keywords: Covid-19, Mental Health, Stress Management, Pandemic 


\section{PENDAHULUAN}

World Health Organization (WHO) telah menyatakan bahwa Corona Virus Disease-19 atau COVID-19 sebagai pandemik atau wabah global. COVID-19 adalah keluarga besar virus yang menyebabkan penyakit mulai dari gejala ringan sampai berat. COVID-19 merupakan jenis baru yang belum pernah diidentifikasi sebelumnya pada manusia. COVID-19 berukuran besar, berdiameter 400-500 mikro. COVID-19 tidak melayang di udara tetapi menempel pada benda atau anggota tubuh. COVID-19 ditularkan melalui kelelawar dan ular ke manusia, sedangkan penularan dari manusia ke manusia melalui droplet atau partikel air liur ketika penderita bersin atau batuk (WHO, 2020).

Pandemi COVID-19 merupakan bencana non alam yang dapat memberikan dampak pada kondisi kesehatan jiwa dan psikososial setiap orang. Sampai dengan tanggal 25 Maret 2020, dilaporkan total kasus konfirmasi COVID-19 sejumlah 414.179 dengan 18.440 kematian (CFR 4,4\%) yang dilaporkan di 192 negara/wilayah. Di antara kasus tersebut, sudah banyak petugas kesehatan yang dilaporkan terinfeksi COVID-19. Pada tanggal 12 April 2020, Di Indonesia, berdasarkan data pada Jumat tgl 25 September 2020 pukul $12.00 \mathrm{WIB}$, tercatat ada 4.823 kasus Covid-19 dalam 24 jam terakhir. Penambahan pasien itu menyebabkan kasus Covid-19 di Indonesia kini mencapai 266.845 orang, terhitung sejak diumumkannya kasus pertama pada 2 Maret 2020 (Kompas, 2020). Desa Kuok yang termasuk ke dalam salah satu desa di Kecamatan Kuok Kabupaten Kampar juga terkena dampak dari wabah COVID-19. Berdasarkan data pada tgl 31 Agustus 2020, terdapat 5 orang pasien yang terkonfirmasi menderita Covid-19.

Menurut WHO (2020), munculnya pandemi menimbulkan stress pada berbagai lapisan masyarakat. Meskipun sejauh ini belum terdapat ulasan sistematis tentang dampak COVID-19 terhadap kesehatan jiwa, namun sejumlah penelitian terkait pandemi (antara lain flu burung dan SARS) menunjukkan adanya dampak negatif terhadap kesehatan mental penderitanya. Penelitian pada penyintas SARS menunjukkan bahwa dalam jangka menengah dan panjang, 41-65\% dari penyintas mengalami berbagai macam gangguan psikologis (Maunder, 2009). Sebuah penelitian di Hong Kong menunjukkan bahwa masalah psikologis pada penyintas SARS tidak berkurang dalam kurun waktu satu tahun setelah kejadian. Bahkan, diperkirakan $64 \%$ dari penyintas berpotensi mengalami gangguan psikiatrik (Lee, dkk, 2007). Adapun faktor risiko terbesar untuk mengalami berbagai distress psikologis terdapat pada perempuan dan tenaga kesehatan. Sebuah penelitian yang juga dilakukan di Hong Kong bahkan menunjukkan bahwa 30 bulan paskainfeksi SARS, 25,6\% dari penyintas mengalami Post Traumatic Disorders (PTSD) dan 15,6\% mengalami gangguan depresi. Secara rata-rata, setidaknya $30 \%$ penyintas mengalami salah satu dari gejala tersebut (Mak, dkk, 2009).

Survey yang dilakukan oleh Ikatan Perawat Kesehatan Jiwa (IPKJI) dan Departemen Keperawatan Jiwa UI pada 2.155 perawat di RS dan Puskesmas pendemi Covid-19 menunjukkan bahwa sebanyak 70,3\% (1557 orang) merasa cemas, tegang dan khawatir akan terkena wabah Covid-19. Berdasarkan survey yang dilakukan di Desa Kuok Kecamatan Kuok didapatkan data bahwa sebagaian orang merasa khawatir, tegang, dan cemas akan tertular Covid-19. Respon psikososial pada masa pandemi Covid-19 berdasarkan hasil observasi antara lain takut tertular, takut meninggal, merasa tidak berdaya, takut diasingkan, takut terpisah dari keluarga karena aturan karantina, takut dating ke fasilitas layanan kesehatan, takut kehilangan pekerjaan, dan merasa tidak berdaya untuk melindungi orang -orang terkasih.

Mengingat adanya risiko peningkatan masalah kesehatan jiwa dan gangguan kejiwaan akibat COVID-19 di masyarakat, maka perlu dilakukan kegiatan pemberian dukungan kesehatan jiwa dan psikososial yang dapat memberikan pilihan kepada masyarakat dalam hal dukungan kesehatan jiwa dan psikososial. Upaya promosi kesehatan jiwa yang dilakukan pemerintah belum maksimal menjangkau masyarakat. Hal ini dibuktikan dengan belum adanya kader kesehatan jiwa di Desa Kuok. Pelayanan kesehatan jiwa masih berfokus pada kuratif seperti rujukan pasien yang mengalami masalah kesehatan jiwa. Apabila upaya promotif dan preventif kesehatan jiwa tidak gencar dilakukan maka angka masalah kejiwaan dan gangguan jiwa dapat meningkat.

Salah satu upaya yang dapat dilakukan untuk memelihara, menjaga dan meningkatkan kesehatan jiwa pada masa pandemi Covid-19 adalah dengan cara mengelola stress atau manajemen stress. Manajemen stress adalah dimana individu melakukan pengontrolan atau pengatuuran stress. Tujuannnya agar individu mengenal penyebab stress dan mengetahui tehnik-tehnik mengelola 
stress, sehingga individu tersebut lebih baik dalam menguasai stress dalam kehidupan, sehingga pada akhirnya kondisi sehat mental dapat dicapai.

\section{METODE}

Adapaun solusi yang ditawarkan kepada mitra adalah metode pengontrolan atau pengelolaan stress pada masa pandemik dengan rincian kegiatan sebagai berikut:

1. Langkah Pertama, SDM mitra diajarkan untuk mengkaji tanda dan gejala stress yang dialami menggunakan kuesioner Self Repoting Questionnaire-29 (SRQ-29).

2. Langkah Kedua, SDM mitra diberikan pendidikan kesehatan atau penyuluhan tentang stress dan cara mengelola stress pada masa pandemic Covid-19

3. Langkah Ketiga, SDM mitra diberikan pelatihan tentang cara mengelola stress pada masa pandemi Covid-19. Adapaun tehnik manajemen stress yang akan diajarkan kepada SDM mitra antara lain:

a. Latihan nafas dalam

Latihan nafas dalam dilakukan dengan cara mengambil posis yang nyaman bisa duduk atau tiduran, tutup mata, Tarik nafas dalam dari hidung ditahan sebentar (3-5 detik) kemudian hembuskan udara perlahan-lahan dari mulut, ulangi 4 sampai 5 kali, evaluasi manfaatnya, dan latih secara rutin 3 sampai 4 kali sehari

b. Latihan relaksasi otot progresif

Relaksasi otot progresif adalah latihan mengencangkan dan mengendorkan otot sambal nafas dalam pada otot muka sampai kaki

c. Latihan berfokus pada lima jari

Latihan berfokus pada lima jari dikenal juga dengan hipnotis lima jari, pasien diminta memokuskan pandangan dan pikiran pada ke lima jari, Tarik nafas dalam, rileks dan kosongkan pikiran.

d. Mengelola emosi

Emosi yang positif seperti kegembiraan akan meningkatkan hormone endorphin, meningkatkan imunitas. Upaya yang dapat dilakukan adalah dengan cara melakukan kegiatan yang menyenangkan atau hobi

e. Penghentian pikiran

Setiap kali muncul pikiran yang mengganggu dan tak dapat mengendalikannya, maka dapat dilakukan penghentian pikiran dengan mengatakan stop

f. Affirmasi

Pikirkan dan tulis pengalaman yang menyenangkan tentang diri sendiri, keluarga, kelompok dan masyarakat. Lakukan affirmasi yaitu dengan mengucapkan pada diri sendiri semua pikiran positif sehingga pikiran dipenuhi oleh pengalaman yang menyenangkan. Selanjutnya susun rencana tujuan yang positif

g. Modifikasi lingkungan

Rumah yang rapi, bersih, tenang dan nyaman akan membantu mengatasi situasi stress. Music atau suara yang lembut juga memberi perasaan rileks

h. Membangun spiritual positif

Melaksanakan ibadah bersama di rumah dengansemua anggota keluarga. Berdoa untuk diri sendiri dan keluarga, masyarakat, tenaga kesehatan dan pemerintah, senantiasa membaca kitab suci dan perbanyak membaca buku-buku agama

4. Langkah Keempat, SDM mitra diberikan modul dan buku evaluasi pelaksanaan kegiatan manajemen stress sebagai pedoman dan evaluasi stress selama pandemi Covid-19

\section{HASIL DAN PEMBAHASAN}

Hasil yang dicapai dalam pelaksaan kegiatan pengabdian kepada masyarakat ini adalah sebagai berikut:

1. Kegiatan koordinasi sekaligus survey tempat pelaksanaan kegiatan pengabdian kepada masyarakat . Kegiatan ini merupakan koordinasi awal dengan pemerintah setempat, dalam hal ini Kepala Desa Kuok dan Kepala Puskesmas Kuok. Setelah mendapatkan persetujuan dan kesepakatan dengan Kepala Desa Kuok dan Kepala Puskesmas Kuok, maka selanjutnya 
dilakukan koordinasi dengan salah satu tempat kegiatan pengajian di Desa Kuok untuk dilaksanakannya kegiatan pengabdian kepada masyarakat.

2. Penyiapan materi pelatihan, modul dan buku evaluasi pelaksanaan kegiatan manajemen stress sebagai pedoman dan evaluasi stress selama pandemi Covid-19

3. Pelaksanaan kegiatan pengabdian kepada masyarakat yang meliputi:

a. Langkah Pertama, SDM mitra diajarkan untuk mengkaji tanda dan gejala stress yang dialami menggunakan kuesioner Self Repoting Questionnaire-29 (SRQ-29).

b. Langkah Kedua, SDM mitra diberikan pendidikan kesehatan atau penyuluhan tentang stress dan cara mengelola stress pada masa pandemic Covid-19

c. Langkah Ketiga, SDM mitra diberikan pelatihan tentang cara mengelola stress pada masa pandemi Covid-19. Adapaun tehnik manajemen stress yang akan diajarkan kepada SDM mitra antara lain:

1). Latihan nafas dalam

Latihan nafas dalam dilakukan dengan cara mengambil posis yang nyaman bisa duduk atau tiduran, tutup mata, Tarik nafas dalam dari hidung ditahan sebentar (3-5 detik) kemudian hembuskan udara perlahan-lahan dari mulut, ulangi 4 sampai 5 kali, evaluasi manfaatnya, dan latih secara rutin 3 sampai 4 kali sehari

2). Latihan relaksasi otot progresif

Relaksasi otot progresif adalah latihan mengencangkan dan mengendorkan otot sambal nafas dalam pada otot muka sampai kaki

3). Latihan berfokus pada lima jari

Latihan berfokus pada lima jari dikenal juga dengan hipnotis lima jari, pasien diminta memokuskan pandangan dan pikiran pada ke lima jari, Tarik nafas dalam, rileks dan kosongkan pikiran.

4). Mengelola emosi

Emosi yang positif seperti kegembiraan akan meningkatkan hormone endorphin, meningkatkan imunitas. Upaya yang dapat dilakukan adalah dengan cara melakukan kegiatan yang menyenangkan atau hobi

5). Penghentian pikiran

Setiap kali muncul pikiran yang mengganggu dan tak dapat mengendalikannya, maka dapat dilakukan penghentian pikiran dengan mengatakan stop

6). Affirmasi

Pikirkan dan tulis pengalaman yang menyenangkan tentang diri sendiri, keluarga, kelompok dan masyarakat. Lakukan affirmasi yaitu dengan mengucapkan pada diri sendiri semua pikiran positif sehingga pikiran dipenuhi oleh pengalaman yang menyenangkan. Selanjutnya susun rencana tujuan yang positif

7). Modifikasi lingkungan

Rumah yang rapi, bersih, tenang dan nyaman akan membantu mengatasi situasi stress. Musik atau suara yang lembut juga memberi perasaan rileks

8). Membangun spiritual positif

Melaksanakan ibadah bersama di rumah dengan semua anggota keluarga. Berdoa untuk diri sendiri dan keluarga, masyarakat, tenaga kesehatan dan pemerintah, senantiasa membaca kitab suci dan perbanyak membaca buku-buku agama

d. Langkah Keempat, SDM mitra diberikan modul dan buku evaluasi pelaksanaan kegiatan manajemen stress sebagai pedoman dan evaluasi stress selama pandemi Covid-19

Pelaksanaan kegiatan PkM dihadiri oleh 30 masyarakat Desa Kuok Kecamatan Kuok. Masyarakat diberikan formulir Self Repoting Questionnaire-29 (SRQ-29), yang digunakan untuk mengkaji tanda dan gejala stress selama pandemic Covid-19. Self Reporting Quetionnaire 29 (SRQ 29) merupakan kuesioner yang dikembangkan oleh World Health Organization (WHO) sebagai alat ukur adanya masalah/gangguan jiwa. SRQ 29 berisi 29 pertanyaan yang berhubungan dengan masalah yang mungkin mengganggu selama 30 hari terakhir. Setiap gangguan yang ditemukan sebaiknya segera dilakukan intervensi untuk mengatasinya.

Berdasarkan hasil Self Repoting Questionnaire-29 (SRQ-29), diketahui bahwa sebagian besar masyarakat $(63,3 \%)$ mengalami tanda dan gejala neurosis yang mengindikasikan adanya masalah 
psikososial selama pandemi Covid-19. Keluhan yang terbanyak adalah keluhan somatis seperti sakit kepala (48\%), kehilangan nafsu makan (34\%), merasa tidak enak di perut (28\%), dan gangguan pencernaan $(25 \%)$. Keluhan mental emosional lainnya yang paling banyak dikeluhkan oleh masyarakat adalah mudah lelah (39\%), gangguan tidur (34\%), dan lelah sepanjang waktu (27\%).Gangguan mental emosional ditegakkan jika seseorang mengalami 6 keluhan ataulebih dari pertanyaan 1 sampai 20 atau mengalami salah satu keluhan dari pertanyaan 21 sampai 29.

Stres bisa dialami oleh setiap orang di dalam kehidupan sehari-hari dan penyebabnya sangat bervariasi, dalam hal ini sebagian besar disebakan oleh situasi pendemi Covid-19. Stres yang dialami tersebut dapat menimbulkan gangguan mental emsosioanl seperti ansietas atau kecemasan Ansietas adalah perasaan cemas terhadap hal yang penyebabnya tidak jelas atau tidak diketahui secara pasti. Ansietas terdiri dari beberapa tahapan antara lain ansietas ringan, ansietas sedang, ansietas berat dan panik (Stuart, Keliat, Pasaribu, 2016). Dalam kehidupan sehari -hati, pada umumnya individu mengalami ansietas ringan. Ansietas ringan tergolong baik dialami oleh seseorang, oleh karena dapat memberikan motivasi untuk menyelesaikan target yang perlu dicapai atau meyelesaikan masalah yang sedang dihadapi. Seseorang yang mengalami ansietas ringan menunjukkan tanda dan gejala antara lain jantung berdebar-debar, sakit kepala, sampai dengan terjadi peningkatan tekanan darah. Gejala yang disampaikan oleh masyarakat ini didukung oleh teori tentang level ansietas, yang mana terdapat empat level ansietas dengan gejalanya yang berbeda-beda mulai dari ansietas ringan, sedang, berat sampai dengan panik. Ansietas ringan merupakan ansietas yang biasanya dialami saat terjadi ketegangan hidup sehari-hari. Ansietas ringan memberikan dampak yang baik bagi seseorang karena dapat memberikan motivasi dan mencegah individu mengalami suatu masalah. Ansietas sedang terjadi oleh karena ketegangan yang lebih berat lagi. Ansietas sedang membuat individu menajdi hanya berfokus pada hal yang sangat penting saja. Ansietas sedang membuat individu menjadi kurang perhatian terhadap apa yang ia lihat dan dengar. Tanda dan gejala fisik yang menyertai pada tingkatan ini seperti banyak berkeringat, merasa gelisah, mondar-mandir serta wajah tampak pucat. Tingkatan selanjutnya yaitu ansietas berat. Individu yang mengalami ansietas berat mengalami penurunan pada kemampuan mempersepsikan sesuatu. Ketika berada pada ansietas berat, seseorang perlu bantuan untuk dapat fokus berpikir.Tahap yang paling tinggi dari ansietas yaitu tahapan panik. Kondisi panik berkaitan dengan rasa takut dan teror. Individu yang berada pada tahap ini tidak dapat melakukan hal apapun meskipun dengan diberikan arahan. Terjadi penurunan kemampuan dalam berhubungan dengan orang lain. Terdapat peningkatan aktivitas motorik seperti gemetar dan sebagainya. Tubuh pun memberikan respon terhadap kondisi panik ini, terjadi peningkatan tekanan darah dan tanda-tanda vital yang lainnya (Stuart, Keliat, Pasaribu, 2019).

Setelah masyarakat megetahui kondisi kesehatan mentalnya selama pandemic Covid-19 ini, selanjutnya masyarakat diberika penyuluhan tentang stress dan manajemen stres. Sebelum diberikan penyuluhan, masyarakat diminta menyampaikan cara yang biasa mereka lakukan untuk mengurangi stress yang dialami. Masyarakat mengungkapkan bahwa hal yang dilakukan ketika menghadapi stress dan ansietas biasanya yaitu berdoa, mengalihkan dengan cara bercerita dengan orang yang mereka percaya, akan tetapi ada juga yang memendam di dalam hati. Masyarakat menyampaikan bahwa belum pernah diadakan penyuluhan terkait cara-cara menangani stres atau ansietas sehingga mereka menangani stres dengan cara yang mereka mampu dan yang mereka ketahui saja.

Pengelolaan stres dan ansietas masyarakat yang diajarkan yaitu latihan napas dalam, latihan relaksasi otot progresif, latihan berfokus pada lima jari, mengelola emosi, penghentian pikiran, afirmasi positif, modifikasi lingkungan dan membangun spiritual positif. Cara mengelola stress ini dapat dilakukan secara mandiri oleh masyarakat ketika sedang berada pada kondisi stres dan ansietas. Latihan relaksasi napas dalam efektif dalam menurunkan tingkat stres pada individu. Latihan relaksasi napas dalam juga diaplikasikan pada beberapa teknik manajemen stres seperti latihan berfokus pada 5 jari dan relaksasi otot progresif. Terdapat perubahan psiko-fisiologi pada tubuh dengan melakukan teknik relaksasi napas dalam. Teknik bernapas lambat mempengaruhi sistem saraf pusat dan otonom yang secara khusus berdampak terhadap jantung dan paru-paru (Creswell et al., 2014). Bila dikaitkan dengan tingkat stress dan ansietas, latihan relaksasi napas dalam dapat diterapkan pada stress dengan tingkatan ringan sampai sedang saja. Pada level ansietas berat dan stress berat, individu cenderung sulit memfokuskan pikiran dan mengendalikan 
diri sehingga akan sulit menerapkan latihan napas dalam. Setelah dijelaskan tentang cara melakukan latihan napas dalam, tim pengabmas meminta masyarakat untuk mengulangi kembali tahapan teknik relaksasi napas dalam. Semua masyarakat tampak mampu mempraktikkan teknik latihan napas dalam dengan baik sesuai dengan tahapan yang diajarkan. Teknik manajemen stress dan ansietas lainnya yang diajarkan yaitu latihan relaksasi otot progresif.

Relaksasi otot progresif diajarkan pada masyarakat karena dapat dilakukan secara mandiri, kapan pun dan dimanapun seseorang berada. Relaksasi otot progresif tidak memerlukan peralatan tertentu dalam pengaplikasiannya, individu hanya menggunakan dirinya sendiri. Teknik ini dilakukan dari otot wajah hingga otot kaki. Otot area tertentu dikontraksikan sembari individu menarik napas dalam, kemudian otot di relaksasikan bersamaan dengan napas dihembuskan melalui mulut secara perlahan. Relaksasi otot progresif telah diteliti dapat menurunkan tingkat stres pada individu (Maghfirah, Sudiana, \& Widyawati, 2015). Penelitian lainnya yang juga meneliti tentang relaksasi otot progresif memberikan hasil bahwa terdapat pengaruh yang signifikan antara pemberian terapi dengan tingkat depresi (Alfiyanti, Setyawan, Kusuma, 2014). Relaksasi otot progresif dilakukan pada beberapa area meliputi area wajah, leher, punggung, anggota gerak atas, anggota gerak bawah. Ketika mempraktikkan latihan relaksasi otot progresif, masyarakat kembali mempraktikan teknik relaksasi napas dalam.

Teknik selanjutnya yang digunakan untuk menurunkan tingkat stress dan ansietas yaitu latihan berfokus pada lima jari. Latihan berfokus pad lima jari juga dapat digunakan untuk menurunkan ansietas. Teknik ini membutuhkan seorang pemandu untuk mengarahkan individu dalam membayangkan hal-hal yang menyenangkan. Teknik ini baik digunakan untuk individu yang sehat maupun yang memiliki gangguan fisik dan sedang mengalami ansietas. Satu penelitian membuktikan bahwa latihan berfokus pada lima jari dapat menurunkan tingkat ansietas pada pasien dengan masalah fisik baik yang baru pertama kali dirawat di rumah sakit maupun klien yang sudah pernah dirawat sebelumnya di rumah sakit (Rizkiya \& Susanti, 2017). Saat pelaksanaan latihan berfokus pada lima jari, masyarakat yang diajarkan teknik ini dapat mengikuti arahan dari pemandu dengan baik. Saat melakukan latihan ini, tim membuat suasana yang tenang dalam melaksanakan latihan berfokus pada lima jari ini. Masyarakat diminta untuk menutup mata, sambal mengatur napas. Kemudian dengan dipandu oleh penyuluh, masyarakat diminta untuk membayangkan: tempat yang paling membuatnya merasa nyaman, membayangkan bila ia berada pada kondisi tertentu dimana merasa sangat sehat, membayangkan pencapaian yang pernah ia alami sehingga ia merasa sangat bangga, serta diminta membayangkan orang yang paling berarti di dalam hidupnya. Penggunaan latihan berfokus pada lima jari ini akan lebih efektif apabila dilakukan dengan kolaborasi teknik relaksasi napas dalam. Hal ini didukung oleh sebuah penelitian yang menyebutkan bahwa terdapat penurunan ansietas pada pasien dengan penyakit fisik yang diberikan treatment relaksasi napas dalam serta hypnosis lima jari (Febrina \& Malfasari, 2018).

Mengelola emosi merupakan latihan berikutnya yang diajarkan kepada masyarakat untuk mengelola stress dan ansietas. Emosi yang positif seperti kegembiraan akan meningkatkan hormone endorphin, meningkatkan imunitas. Upaya yang dapat dilakukan oleh masyarakat adalah dengan cara melakukan kegiatan yang menyenangkan atau hobi seperti menyanyi, menyulam, memancing dan lain sebagainya. Penghentian pikiran juga menjadi salah satu latihan yang diajarkan kepada masyarakat. Masyarakat dilatih mengatakan "Stop" setiap kali muncul pikiran yang mengganggu dan tak dapat mengendalikannya. Latihan mengungkapkan pikirkan dan menuliskan pengalaman yang menyenangkan tentang diri sendiri, keluarga, kelompok dan masyarakat dilakukan pada sesi latihan affirmasi. Latihan affirmasi dilakukan dengan mengucapkan pada diri sendiri semua pikiran positif sehingga pikiran dipenuhi oleh pengalaman yang menyenangkan. Selanjutnya susun rencana tujuan yang positif.

Pengelolan stress pada masa pandemic Covid-29 juga dapat dilakukan dengan memodifikasi lingkungan. Masyarakat diajarkan memodifikasi rumah yang rapi, bersih, tenang dan nyaman sehingga akan membantu mengatasi situasi stress. Musik atau suara yang lembut juga memberi perasaan rileks pada seseorang yang mengalami stress. Latihan terakhir yang diajarkan kepada masyarakat adalah dengan cara membangun spiritual positif. Melaksanakan ibadah bersama di rumah dengan semua anggota keluarga. Berdoa untuk diri sendiri dan keluarga, masyarakat, tenaga kesehatan dan pemerintah, senantiasa membaca kitab suci dan perbanyak membaca buku-buku agama merupakan cara-cara yang bisa menjadi pilihan masyarakat untuk mengatasi stress. 
Kegiatan latihan manajemen stress diakhiri dengan memberikan modul dan buku evaluasi pelaksanaan kegiatan manajemen stress sebagai pedoman dan evaluasi stress selama pandemi Covid-19.

\section{SIMPULAN}

Kegiatan pengabdian kepada masyarakat yang berbentuk penyuluhan dan pelatihan manajemen stres dan ansietas masyarakat di Desa Kuok Kecamatan Kuok ini berhasil memberikan dampak berupa peningkatan pengetahuan masyarakat terkait kesehatan jiwa, stres, ansietas serta cara penanganan stres dan ansietas oleh masyarakat selama pandemic Covid-19. Manajemen stres dan ansietas masyarakat yang telah diajarkan berupa latihan napas dalam, latihan relaksasi otot progresif, latihan berfokus pada lima jari mengelola emosi, penghentian pikiran, afirmasi positif, modifikasi lingkungan dan membangun spiritual positif. Beberapa teknik manajemen stres dan ansietas yang diajarkan ini tetap membutuhkan partisipasi setiap masyarakat untuk konsisten melakukan latihan secara mandiri. Diharapkan masyarakat dapat menangani stres dan ansietas sehari-hari terutama selama pandemic Covid-19 secara mandiri sehingga tercipta masyarakat yang sehat jiwa.

\section{SARAN}

Kegiatan ini diharapkan tidak berakhir pada kegiatan pengabdian saja, tetapi bisa dibentuk kerjasama dalam penyebaran informasi tentang bagaimana mengelola stress selama pandemic Covid-19.

\section{UCAPAN TERIMA KASIH}

1. Prof. DR. H. Amir Luthfi selaku Rektor Universitas Pahlawan Tuanku Tambusai

2. Ibu Dewi Anggriani Harahap, M. Keb selaku Dekan Fakultas Ilmu Kesehatan Universitas Pahlawan Tuanku Tambusai

3. Ibu Ns. Apriza, M. Kep selaku Ketua LPPM Universitas Pahlawan Tuanku Tambusai

4. Kepala Desa Kuok

5. Kepala Puskesmas Kuok

6. Kelompok Pengajian Desa Kuok

\section{DAFTAR PUSTAKA}

Bao Y, Sun Y, Meng S, Shi J, Lu L. (2019). -NcoV epidemic:address mental health care to empowersociety. Lancet. https://doi.org/10.1016/S0140-6736(20)30309-3

Centers for Disease Control and Prevention (CDC). Supplement: Community Containment Measures, Including Non Hospitasi Isolation and Quarantine. https://www.cdc.gov/sars/guidance/d-quarantine/app3.html

Himpunan Psikologi Indonesia (HIMPSI). (2020). Panduan Layanan Psikologi dalam Masa Tanggap Darurat COVID-19 bagi Psikolog, Sarjana Psikolog, Asisten Psikolog dan Praktisi Psikolog.

IASC. 2020. Briefing note on adressing mental health and psychosocial aspects of COVID-19 Outbreak- Version 1.1.

Ikatan Psikolog Klinis Indonesia. 2020. Panduan Layanan Psikologi Klinis dalam Rangka Penanggulangan Pandemi COVID-19

Ikatan Pekerja Sosial Profesional Indonesia. 2020. Panduan Praktik Perkejaan Sosial dalam Situasi COVID-19; Khusus bagi Pekerja Sosial Indonesia

Kementerian Kesehatan RI. 2019. Pedoman Pencegahan dan Pengendalian Coronavirus Disease ( COVID-19)

Keliat, B.A, Marliana, T. 2018. Dukungan Kesehatan Jiwa dan Psikososial (Mental Health and Psycho Social Support ): Keperawatan Jiwa. Jakarta: ISBN: 978-602-1238-51-6

Keliat, B.A, Hamid, A. Y. S, Putri, Y. S. E, Daulima, N. H. C, Wardani, I. Y, Susanti, H, Hargiana, G, \& Panjaitan, R. U. 2019. Asuhan Keperawatan Jiwa. Jakarta: Penerbit Buku Kedokteran, EGC 
Keliat, B.A, Marliana, T, Windarwati, H. W, Mubin, M. F, Sodikin, M. A, Prawiro, A. D, Trihadi, D, \& Kembaren, L. 2020. Dukungan Kesehatan Jiwa dan Psiko Sosial (Mental Health and Psycho Social Support) COVID-19: Keperawatan Jiwa. Jakarta: ISBN: dalam proses

Kompas. 2020. UPDATE: Bertambah 4.823, Kini Ada 266.845 Kasus Covid-19 di Indonesia. https://nasional.kompas.com

Pemkab Kampar. 2020. Data pantauan Covid Kabupaten Kampar. https://corona.kamparkab.go.id/ Undang- Undang Nomor 18 Tahun 2014 tentang Kesehatan Jiwa

WHO. Helping children cope with stress during the 2019-Ncov outbreak (Handout). WHO: Jenewa, 2020

WHO. 2020. Mental health and psychosocial considerations during the COVID-19 outbreak

WHO. 2005. Briefing Note on Psychosocial/Mental Health Assistance to the Tsunami-Affected Region. WHO: Departement of Mental Health and Subtance Abuse

WHO \& United Nations High Commissioner for Refugess mhGAP Humanitarian Intervention Guide (mhGAP-HIG): 2015. Clinical Management of Mental, Neurological and Subtance Use Conditions in Humanitarian Emergencies. WHO: Ganeva

Surat Keputusan Pengurus Pusat Perhimpunan Dokter Spesialis Kedokteran Jiwa Indonesia ( PDSKJI) No. 011/SK/PDSKJ//III/2020 Tentang Panduan Interaksi Obat Psikiatri dengan Obat COVID-19. Jakarta

Surat Keputusan Pengurus Pusat Perhimpunan Dokter Spesialis Kedokteran Jiwa Indonesia (PDSKJI) No. 010/SK/PDSKJI/III/2020 Tentang Panduan Penatalaksanaan untuk Psikiater yang Bertugas di Layanan Kesehatan Jiwa di Era Pandemi COVID-19. Jakarta 